\title{
Spontaneous apoptosis in primary cultures of human and rat hepatocytes: molecular mechanisms and regulation by dexamethasone
}

\author{
B Bailly-Maitre ${ }^{1,4}$, G de Sousa*,1, N Zucchini ${ }^{1}$, J Gugenheim², \\ KE Boulukos ${ }^{3}$ and R Rahmani ${ }^{\star, 1}$ \\ ${ }^{1}$ Laboratoire de Pharmaco-Toxicologie Cellulaire et Moléculaire, INRA, 06606 \\ Antibes, France. \\ ${ }^{2}$ Laboratoire de Chirurgie Expérimentale-Faculté de Medecine, 06107 Nice \\ Cedex 02, France. \\ 3 Institute of Signaling, Developmental Biology and Cancer Research, Centre de \\ Biochimie, Université de Nice, Faculté des Sciences, 06108 Nice, France. \\ ${ }^{4}$ Current address: The Burnham Institute, La Jolla, San Diego, California, CA \\ 92121, USA \\ * Corresponding authors: $\mathrm{G}$ de Sousa or R Rahmani, Laboratoire de Pharmaco- \\ Toxicologie Cellulaire et Moléculaire, INRA, 06606, Antibes, France. \\ Tel : 334936788 60; Fax: 334936730 40; \\ E-mail: de sousa or rahmani@antibes.inra.fr.
}

Received 30.11.01; revised 5.2.02; accepted 14.2.02

Edited by M Piacentini

\section{Abstract}

To elucidate the biochemical pathways leading to spontaneous apoptosis in primary cultures of human and rat hepatocytes, we examined the activation of the caspase cascade, the expression of Bcl-2-related-proteins and heat shock proteins. Comparisons were made before and after dexamethasone (DEX) treatment. We show that DEX inhibited spontaneous apoptosis in a dose-dependent manner. DEX increases the expression of anti-apoptotic $\mathrm{Bcl}-2$ and $\mathrm{Bcl}-\mathrm{x}_{\mathrm{L}}$ proteins, decreases the expression of pro-apoptotic Bax and inhibits Bad translocation thereby preventing the release of cytochrome $c$, the activation of caspases, and cell death. Although, the expression of Hsp27 and Hsp70 proteins remained unchanged, the oncogenic protein c-Myc is upregulated upon DEX-treatment. These results indicate that DEX mediates its survival effect against spontaneous apoptosis by acting upstream of the mitochondrial changes. Thus, the mitochondrial apoptotic pathway plays a major role in regulating spontaneous apoptosis in these cells. Blocking this pathway therefore may assist with organ preservation for transplant, drug screening, and other purposes.

Cell Death and Differentiation (2002) 9, 945-955. doi:10.1038/ sj.cdd. 4401043

Keywords: apoptosis; primary human and rat hepatocytes; $\mathrm{Bcl}-2$ family; caspase-8; caspase-9; cytochrome $c$

Abbreviations: AP-1, activator protein-1; CAD, caspase-activated deoxyribonuclease; Cyto $c$, Cytochrome $c$; DEX, dexamethasone; FBS, foetal bovine serum; BSA, bovine serum albumin; MTT, 3-(4,5dimethylthiazol-2-yl)-2,5-diphenyl tetrazolium bromide; DMSO, dimethyl sulfoxide; PBS, phosphate buffer saline; TdT, Terminal deoxynucleotidyl transferase; DEVD-AFC, N-acetyl-Asp-Glu-ValAsp-aminotrifluoromethylcoumarin; DTT, dithiothreitol; Hsp, Heat ShockProtein; SDS, sodium dodecyl sulphate; NT, non-treated cells; Control-cells, DMSO-treated cells (-); TNF, tumour necrosis factor; TUNEL, TdT-mediated dUTP Nick End Labelling; Fas-L, FasLigand; Fas, Fas-receptor; FADD, Fas- associated death domain protein; DD, death domain; DED, death effector domain; PI3-kinase, phosphoinositide 3-kinase; TIAR, TIA-1-related RNA-binding protein; CAS, cellular apoptosis susceptibility protein

\section{Introduction}

The mechanisms that regulate programmed cell death are essential for normal development and for the maintenance of homeostasis. Several recent studies have addressed the role of apoptosis in liver physiology and pathology. Apoptosis is rarely detected in healthy adult liver, however, a significant increase in apoptosis can be observed upon treatment with cytokines or chemicals (e.g., transforming growth factor- $\beta_{1}$ (TGF- $\beta_{1}$ ), anti-Fas/ APO-1 antibody, cycloheximide), during liver regression, or under certain clinical situations (e.g., viral hepatitis). ${ }^{1-4}$ Since the liver is the largest internal organ of the body and performs a wide range of vital biochemical processes, the occurrence of uncontrolled apoptosis may cause impaired hepatic functions which could lead to aberrations in other organ systems and ultimately to death. Thus, the knowledge of the molecular mechanisms inducing or inhibiting apoptosis in general has provided important insights into the causes of multiple diseases where aberrant cell death regulation occurs, and has revealed new approaches for identifying small drugs for more effectively treating these illnesses. ${ }^{5}$

In ex vivo cultures of primary hepatocytes, liver-specific functions rapidly decrease and cell survival does not exceed a few days ${ }^{6}$ due to spontaneous apoptosis. ${ }^{7-9}$ These phenotypic changes constitute a major limitation in the use of hepatocytes in primary cultures for various applications such as pharmacology and toxicology. Although the molecular mechanisms of death-receptor signalling have been largely elucidated, the mechanisms that regulate spontaneous apoptosis are still unknown in these cells.

Apoptosis is a complex process regulated by the molecular interactions of various gene products. ${ }^{10}$ One of the major classes of gene products that induces apoptosis is the caspase family. The effector caspase, caspase-3, appears to act at the most downstream point in apoptosis. It has been reported to activate a caspase-activated deoxyribonuclease (CAD) through cleavage of its inhibitor (ICAD), leading to DNA fragmentation. ${ }^{11}$ Caspase- 3 is activated by proteolysis mediated by caspase- 8 or caspase-9. Caspase-8 represents the apical caspase in the 
death receptor pathway, ${ }^{12}$ whereas caspase- 9 serves as the apical caspase of the mitochondrial pathway. ${ }^{13}$ The death receptor pathway can be induced by members of the TNFfamily of cytokine receptors, such as TNFR1 and Fas. These proteins recruit adapter proteins to their cytosolic death domains, including FADD, which then bind death effector domains containing procaspases, particularly procaspase-8. The mitochondrial pathway can be activated by release of cytochrome $c$ from mitochondria, induced by various molecular mechanisms, including elevations in the levels of pore forming pro-apoptotic Bcl-2 family proteins, such as Bax and Bad, or physical disruption of the outer membrane as a result of mitochondrial matrix swelling. In the cytosol, cytochrome $c$ binds and activates Apaf-1, allowing it then to bind and activate procaspase-9. Active caspase- 9 and caspase-8, cleave and activate the effector protease caspase- 3 , which in turn activates other caspases and directly cleaves cell death substrates, thus orchestrating the biochemical execution of programmed cell death. ${ }^{14}$ Though capable of operating independently, crosstalks between these pathways can occur at multiple levels. ${ }^{5}$ The function of both pathways can be greatly modified by inclusion of endogenous apoptosis inhibitory proteins, such as the antiapoptotic members of the $\mathrm{Bcl}-2$ family $\left(\mathrm{Bcl}-2\right.$ and $\left.\mathrm{Bcl}-\mathrm{x}_{\mathrm{L}}\right),{ }^{15-17}$ or the members of the heat shock proteins family (Hsp27, Hsp60 and Hsp70).

Several other proteins, downstream caspases, have been shown to participate in the regulation of apoptosis, including the c-Myc, CAS and TIAR proteins. The c-Myc and CAS proteins have been implicated in oncogenesis and apoptosis, promoting both cell division and cell death. ${ }^{18} \mathrm{~A}$ correlation in the levels of protein expression of c-Myc, CAS, Bcl-2 family members and caspase- 3 in numerous hepatic malignancies has been observed. ${ }^{19,20}$ TIAR is supposed to be involved in stress-induced apoptosis. It triggers DNA fragmentation in permeabilized thymocytes and its expression diminishes in the nucleus and rises simultaneously in the cytoplasm during the induction of death receptor pathway. ${ }^{21}$

In this study, we found that DEX inhibits spontaneous apoptosis in primary cultures of both human and rat hepatocytes, in a dose-dependent manner, by acting upstream of mitochondrial changes. DEX decreases the expression of $\mathrm{Bax}$, inhibits $\mathrm{Bcl}-2$ and $\mathrm{Bcl}-\mathrm{x}_{\mathrm{L}}$ downregulation, and Bad translocation from the cytosol to mitochondria, suppresses cytochrome $c$ release and caspase activation. We speculate therefore that arresting the mitochondrial pathway may enhance ex vivo hepatocyte survival, finding applications for organ transplant, drug screening, and other purposes.

\section{Results}

\section{Dexamethasone treatment of human and rat hepatocytes prolongs cell viability in a dose-dependent manner}

It has been shown that spontaneous apoptosis occurs in some cell types in vitro in response to nutrient deprivation and to growth factor withdrawal. ${ }^{22}$ We previously demonstrated that apoptosis was spontaneously activated in primary human and rat hepatocytes cultivated ex vivo and that dexametha- sone significantly prevented this process. ${ }^{9}$ In this study, we wished to determine the mechanism by which DEX protects against spontaneous hepatocyte apoptosis. We first analyzed the effects of increasing concentrations of dexamethasone on hepatocyte viability, by using the MTT dye-reduction assay. ${ }^{7}$ As expected, in untreated- (NEG) and DMSO-treated human hepatocytes cultured ex vivo, the percentage of viable cells dropped rapidly after day 5 (Figure 1). At day 9, only $5-10 \%$ of cells remained viable. In contrast, DEX clearly exerts a protective effect from $0.01 \mu \mathrm{M}(30 \%$ viable cells) to $50 \mu \mathrm{M}$ (95\% viable cells). The spontaneous loss of viability beginning on day 5 was reversed in a concentration- and timedependent manner in DEX-treated cells, with a maximal effect at $50 \mu \mathrm{M}$ (Figure 1).

To determine whether the effects of dexamethasone on hepatocyte survival are specific to human hepatocytes or are more general in affecting hepatocyte survival in other species as well, we performed similar experiments as described below using primary cultures of rat hepatocytes. Based on cell viability, treatment with increasing concentrations of DEX permitted rat hepatocyte survival in a similar fashion to that observed with human hepatocytes (data not shown).

\section{DEX decreases activation of caspase-8 without affecting Fas- $L$ and FADD expression in human primary hepatocyte cultures}

We then wished to address the mechanisms by which DEX inhibits spontaneous apoptosis. Death receptor activation or loss of mitochondrial integrity are two major pathways implicated in regulating apoptosis. To investigate the possible changes in death-receptor signalling effectors during spontaneous apoptosis, cell extracts from human and rat hepatocytes after different treatments with DEX were subjected to Western-blot analysis with anti-Fas and anti-Fas- $L$ antibodies (Figure 2A). Fas protein levels decreased with time in control human hepatocytes. In contrast, its expression significantly

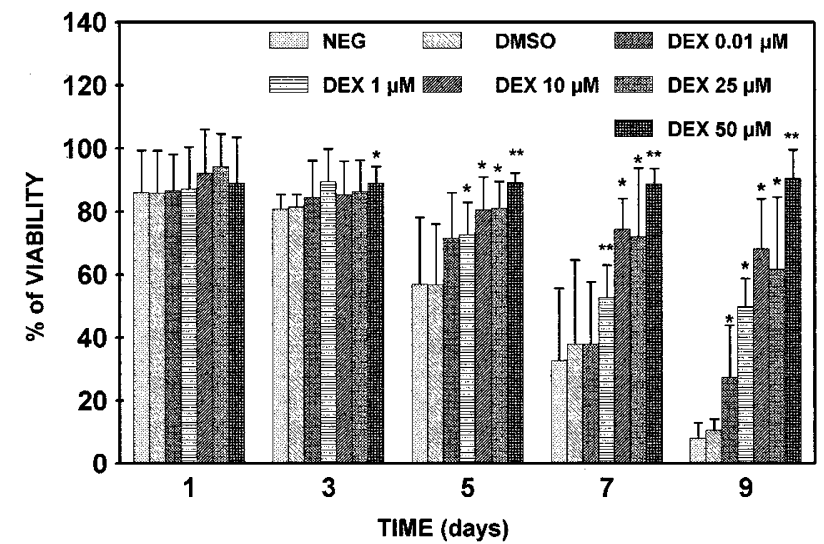

Figure 1 Spontaneous apoptosis is inhibited in a dose-dependent manner in primary cultures of human hepatocytes. Dose-response curves of the effect of DEX on human hepatocyte viability during 9 days of treatment. The concentrations of DEX are indicated at the top right of the figure. Each value is the mean \pm S.D. of three separate experiments done in triplicate $\left({ }^{*}=P<0.05\right.$, $\left.{ }^{* *}=P<0.001\right)$ 
increased after a 3 day treatment with DEX and remained elevated at day 5 in human hepatocytes, coincident with increasing survival and protection against apoptosis in these cells. At later time points, Fas expression decreased in these cells but the levels remained higher than in DMSO-treated cells. However, the level of Fas- $L$ protein decreased in both control- and DEX-treated human hepatocytes over time in a similar fashion. Similar results were obtained using rat hepatocytes.

A wide body of experimental evidence, including gene disruption experiments in mice, has demonstrated that caspase- 8 represents the apical caspase in the death-

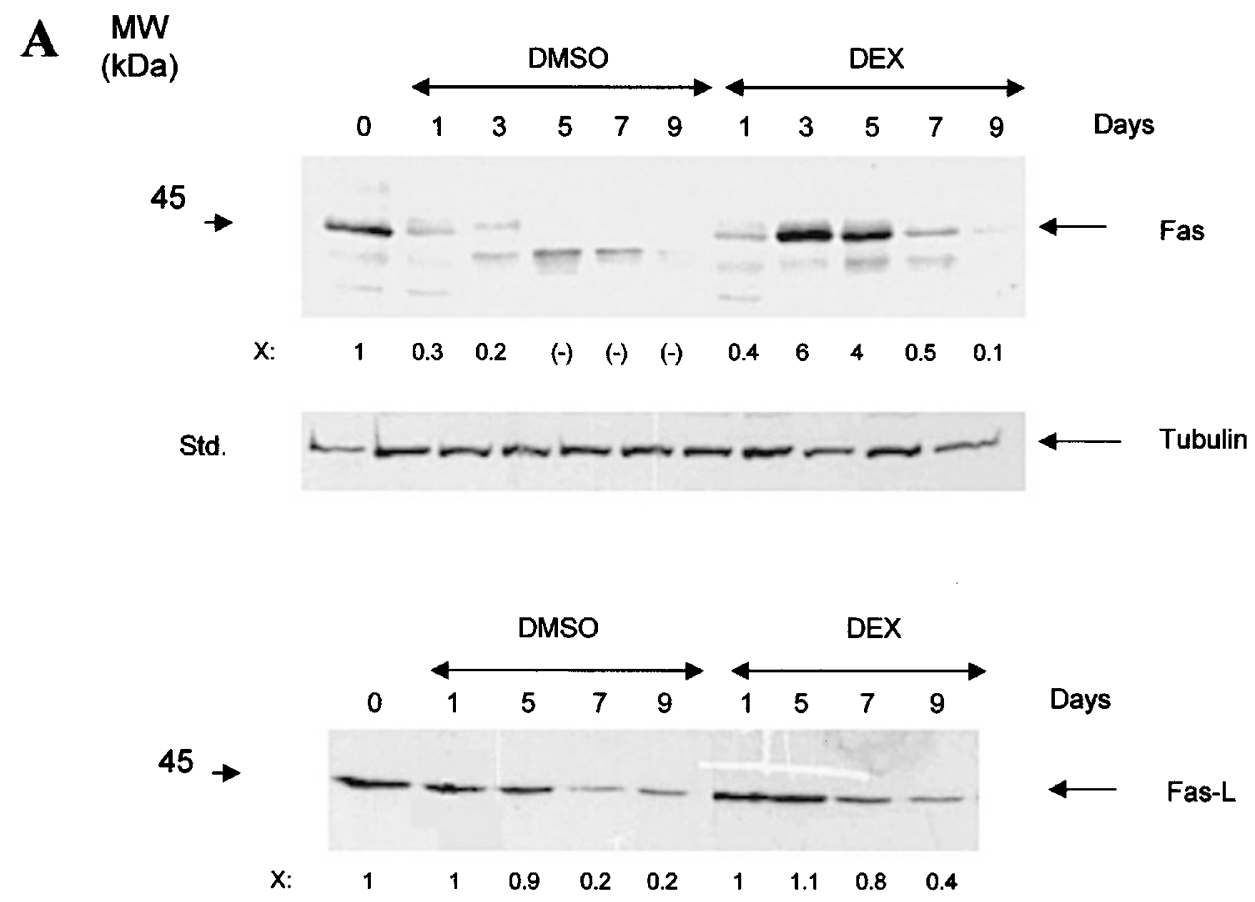

Std.
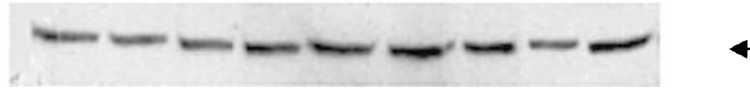

Tubulin

B

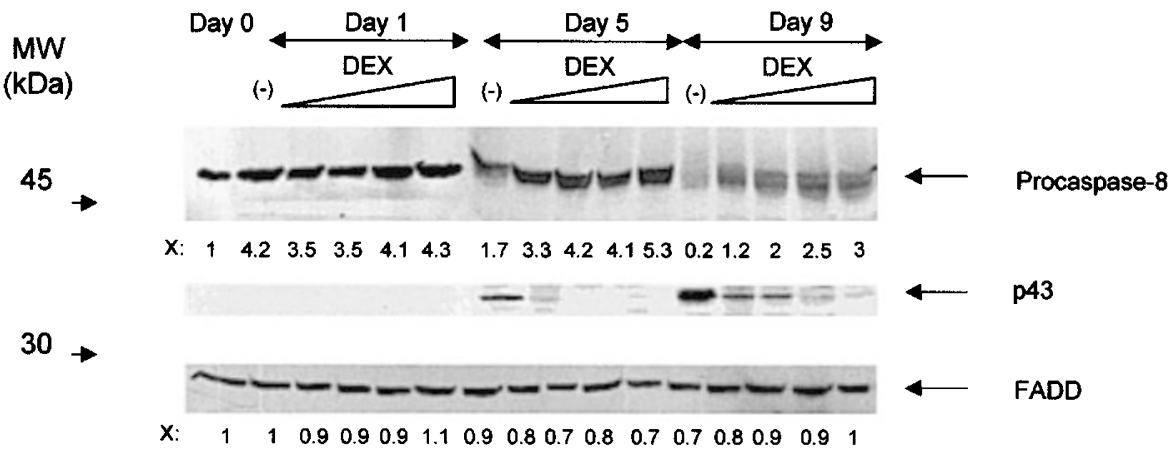

Figure 2 Kinetic study of the expression of Fas, Fas-L, caspase-8, and FADD in human hepatocytes during dexamethasone treatment. (A) The cells were treated with DMSO $(0.25 \%)$ and DEX $(50 \mu \mathrm{M})$ for various lengths of time as indicated. Equal amounts of total extracts were loaded onto a SDS $12.5 \%$ polyacrylamide gel and transferred to a Hybond-P membrane. The blot was then incubated with anti-Fas ( $50 \mathrm{ng} / \mathrm{ml})$ or with anti-Fas- $\mathrm{L}$ ( $25 \mathrm{ng} / \mathrm{ml})$ and processed by ECL as described in the Materials and Methods. Similar results were obtained with different concentrations of DEX $(0.01 \mu \mathrm{M}, 1 \mu \mathrm{M}$ and $10 \mu \mathrm{M})$. Detection of Tubulin proteins has been included as a control for loading and membrane transfer (Std.). (B) Hepatocytes were treated with DMSO ( -$)$ and increasing concentrations of DEX (0.01 $\mu \mathrm{M}, 1 \mu \mathrm{M}$, $10 \mu \mathrm{M}$ and $50 \mu \mathrm{M})$ for 9 days. The blot was incubated with anti-Fas $(50 \mathrm{ng} / \mathrm{ml})$, anti-Fas-L $(25 \mathrm{ng} / \mathrm{ml})$, anti-procaspase-8 (25 ng/ml) and anti-FADD (50 ng/ml) antibodies and processed as described in the Materials and Methods. Fold inductions, determined by a densitometry, are given (X), with one corresponding to the level of proteins at T0 (time at the beginning of treatments). The position of the molecular mass markers (MW), are indicated in thousands at the left of panels. Each immunoblot shown here represents the typical result from several independent experiments. The same results were obtained in rat hepatocytes 
receptor signalling pathway, ${ }^{12,23}$ whereas caspase- 9 serves as the apical caspase of the mitochondrial pathway. ${ }^{13,24}$ As described below, cell extracts from human and rat hepatocytes treated with increasing concentrations of DEX were subjected to Western analysis using antiprocaspase-8 and anti-FADD antibodies (Figure 2B). Procaspases are converted in the active subunits during the course of activation. ${ }^{14,25}$ The mouse monoclonal antihuman caspase-8 antibodies used in this experiment recognised the $55 / 58 \mathrm{kDa}$ procaspase- 8 and its $48 \mathrm{kDa}$ active form. The level of expression of procaspase- 8 clearly did not significantly change at day 1 , but decreased significantly at day 5 in DMSO-treated cells $(-)$, indicating that caspase- 8 was fully activated. In parallel, the expression of the active form of caspase- 8 was increased at the same time (Figure $2 \mathrm{~B}$ ). In contrast, examination of procaspase-8 in DEX-treated cells, revealed a dosedependent decrease in the proportion of processed protease at days 5 to 9. For example, at day 9, procaspase- 8 had been entirely consumed in DMSOtreated cells whereas procaspase-8 remained detectable in DEX-treated cells. Similar results were observed for procaspase-2 (data not shown). In parallel, no obvious changes of the adapter protein FADD were detected (Figure 2B). Again, similar results were observed using rat hepatocytes (data not shown). These findings concerning procaspase-8 processing correlate with the data obtained for cell viability, demonstrating a dose-dependent protection by DEX.

\section{DEX decreases release of cytochrome $c$, and inhibits activation of caspase- 9 and caspase- 3 in primary cultures of human hepatocytes}

We performed kinetic studies to analyse the processing of procaspase- 9 by Western-blotting. In DMSO-treated cells, the level of expression of procaspase- 9 decreased slightly during the experiments to undetectable levels at day 9 (Figure 3A), indicating that caspase- 9 was activated. The most interesting finding was that caspase- 9 was activated with different kinetics than that of caspase-8. Moreover, its activation was inhibited by DEX-treatment, in a time- and concentrationdependent manner. In view of these results, we decided to determine whether the activation of caspase- 9 could be coincident with the release of cytochrome $c$ into the cytosol. As shown Figure 3B, DEX treatment is associated with a decrease of cytochrome $c$ level in the cytosol, with a concomitant increase in mitochondrial cytochrome $c$ level, at day 5 . These effects were specific, since no change was observed in the expression levels of the Tubulin protein and the mitochondrial matrix protein, Hsp60, respectively (Figure 3B). Hsp60 was undetectable in cytosolic fractions, a result which is consistent with the inhibition of procaspase- 9 processing at day 5 in DEX-treated cells.

To corroborate the functionality of cytochrome $c$ in the cytosol, we assayed caspase- 3 activity in cell extracts (Figure $3 C)^{26-28}$ At day 5, release of cytochrome $c$ was coincident with the increase in caspase-3 activity in DMSOtreated cells. This release was strongly decreased in the presence of DEX, coincident with the inhibition of caspase-
3 activity (fivefold over control with DEX $50 \mu \mathrm{M} ; P<0.05$ ). In contrast, DEX caused a concentration-dependent reduction in caspase-3-like protease activity. We further investigated, by Western-blot analysis, whether these changes in proteolytic activity correlated with the cleavage of procaspase-3. As seen in Figure $3 A$, during the same period (from day 5 to day 9), a decrease in the level of procaspase-3 was observed in DMSO- treated cells, suggesting that the proform of this protease was depleted during activation. In contrast, DEX treatment resulted in a concentration-dependent reduction in procaspase-3 consumption.

TIAR is a member of the RNA-recognition motif family of RNA-binding proteins. ${ }^{21}$ Because cytosolic expression of TIAR increases when cells undergo apoptosis associated with DNA fragmentation and caspase-3-like activities, ${ }^{29}$ we investigated its potential role in spontaneous hepatocyte apoptosis. We examined TIAR expression in total (TIARt) and cytosolic (TIARc) human hepatocyte extracts by Western-blot analysis. Two related isoforms (42 and $50 \mathrm{kDa}$ ) of TIAR have been detected (Figure 3D). Timecourse analyses showed an increase of TIARc level in DMSO-treated cells, with increasing time in culture reaching a maximum at day 9 (fivefold; $P<0.05$ ), while redistribution of TIARc into the cytosol is delayed by DEX in a concentrationdependent manner. By contrast, the expression of TIARt remained unchanged. Identical results were obtained in DEXtreated rat hepatocytes (data not shown).

Overexpression of Hsp27 and Hsp70 have been shown to promote cytoprotection and to rescue cells from apoptosis. ${ }^{30}$ Therefore, we examined the potential role of both proteins in human and rat hepatocyte apoptosis by immunoblot analysis. Neither Hsp70 nor Hsp27 levels (Figure $3 A$ and D) changed significantly upon treatment with DEX. Since Hsp27 and Hsp70 protein levels followed ponceau red staining (data not shown), Hsp27 and Hsp70 were used as controls to demonstrate equivalent protein loading and membrane transfer (Std).

\section{Dexamethasone increases $\mathrm{Bcl}-2$ and $\mathrm{Bcl}-\mathrm{x}_{\mathrm{L}}$ expression, decreases Bax expression and inhibits Bad translocation to mitochondria in a dose-dependent manner}

$\mathrm{Bcl}-2$ and $\mathrm{Bcl}-\mathrm{x}_{\mathrm{L}}$ have been shown to have anti-apoptotic effects, whereas Bax and Bad act as inducers of apoptosis, with the balance between these molecules modulating apoptotic processes. ${ }^{10,31,32}$ For these reasons, we decided to analyze whether DEX could modulate the expression of some of the $\mathrm{Bcl}-2$ family proteins by Western blotting (Figure 4). Bcl-2 expression in human hepatocytes was reduced in DMSO treated-cells at day 5 and was hardly detected at day 9 (Figure 4A). However, in DEX-treated-cells, the level of Bcl-2 protein significantly increased in a dose-dependent manner (Figure 4A). At day 5, Bcl-2 protein reached a maximum (fourfold over control; $P<0.05$ ) and remained elevated until day 9 .

$\mathrm{Bcl}-\mathrm{x}_{\mathrm{L}}$, and not $\mathrm{Bcl}-2$, is the major anti-apoptotic protein expressed in rat hepatocytes. ${ }^{4}$ Like Bcl-2 in human cells, Bcl$\mathrm{X}_{\mathrm{L}}$ considerably decreased in DMSO-treated hepatocytes 
A

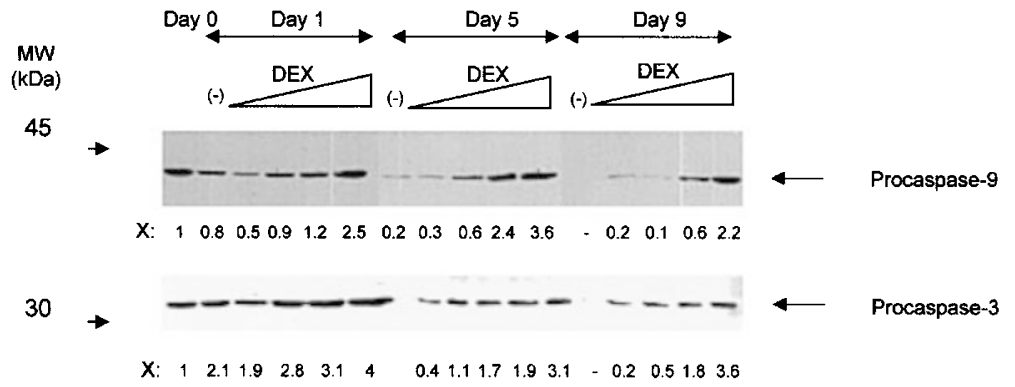

Std.

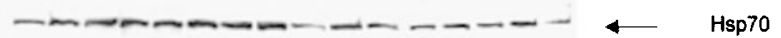

B

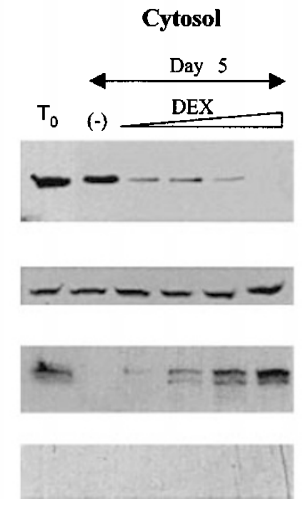

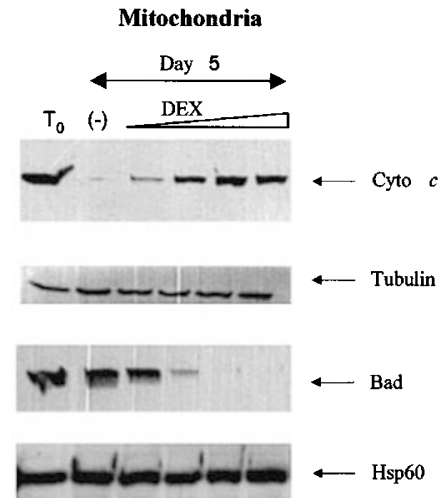

C

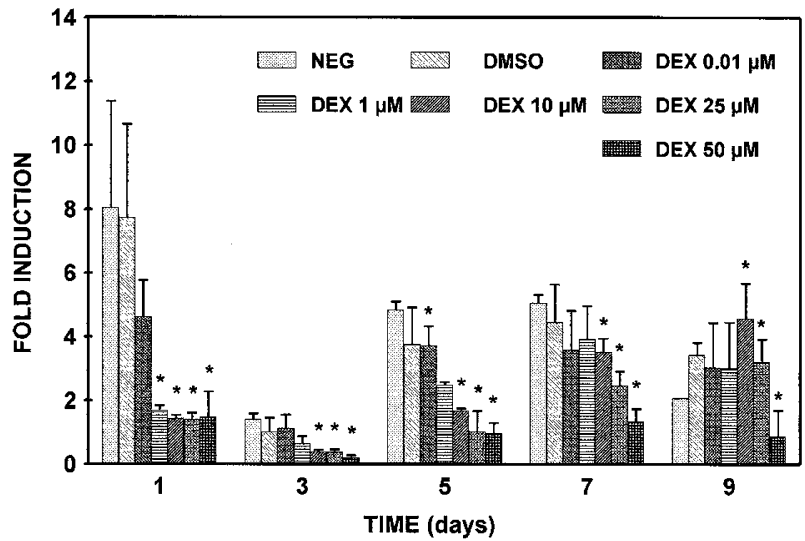

D

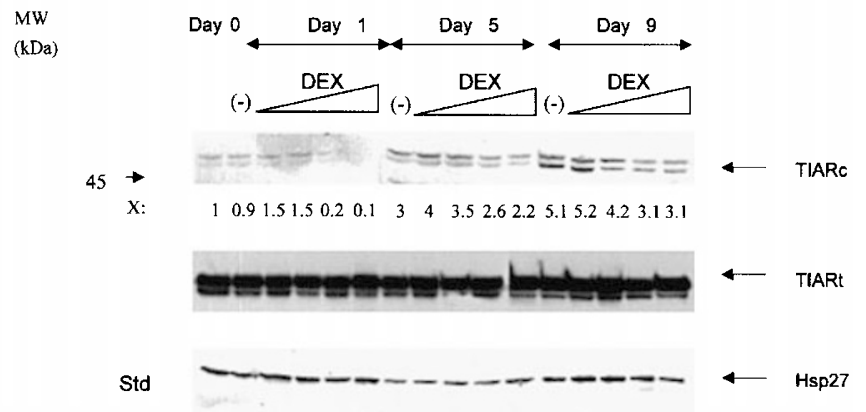

Figure 3 DEX stabilises procaspase-9 and procaspase-3, and DEX inhibits the release of cytochrome $c$ into the cytosol, the translocation of Bad to mitochondria, and the release of TIAR in the cytosol. (A) Human hepatocytes were cultured with DMSO $(0.25 \%)(-)$ and increasing concentrations of DEX $(0.01 \mu \mathrm{M}, 1 \mu \mathrm{M}, 10 \mu \mathrm{M}$ and $50 \mu \mathrm{M}$ ) for various lengths of time as indicated. Equal amounts of total protein lysates were loaded on a 12\% SDS-polyacrylamide gel, and transferred to a Hybond-P membrane. The blot was then probed with anti-procaspase- $9(50 \mathrm{ng} / \mathrm{ml})$, anti-caspase-3 $(50 \mathrm{ng} / \mathrm{ml})$ and anti-Hsp70 $(25 \mathrm{ng} / \mathrm{ml})$ antibodies, then processed by ECL as described in Materials and Methods. (B) Human hepatocytes were cultured with DMSO (-) and increasing concentrations of DEX for 5 days as described below. Cytosolic and mitochondrial extracts were separated by $12.5 \%$ SDS-polyacrylamide gel electrophoresis and analyzed by immunoblotting with anti-cytochrome $c(100 \mathrm{ng} / \mathrm{ml})$ and anti-Bad $(50 \mathrm{ng} / \mathrm{ml})$ antibodies. As a control, filters were also analyzed by immunoblotting with anti-Tubulin $(100 \mathrm{ng} / \mathrm{ml})$ and with anti-Hsp60 $(50 \mathrm{ng} / \mathrm{ml})$ antibodies. Results shown are from one representative experiment of a total of three performed. Similar results were obtained with rat hepatocytes. (C) Time course of caspase-3-like activity. Cytosolic extracts were prepared as described below. Caspase-3-like protease activity was measured with DEVD-AFC using a fluorometric assay. Fold-inductions were calculated with respect to T0 (time at the beginning of treatments) used as the reference (Note. ${ }^{*}=P<0.05$, Means \pm S.D., $n=3$ ). Similar results were obtained with human hepatocytes. (D) DEX decreases TIAR expression in the cytosolic fraction. TIAR expression was analyzed by Western blot in total (TIARt) and cytosolic extracts (TIARc) of control ( - ) and DEX-treated hepatocytes with anti-TIAR antibody (75 ng/ $\mathrm{ml}$ ). The $52 / 55 \mathrm{kDa}$ proteins are indicated by the arrows

(Figure 4B) from day 5 to day 9 and was hardly detected at day 9. Similarly, DEX treatment upregulated $\mathrm{Bcl}-\mathrm{x}_{\mathrm{L}}$ in rat hepatocytes in a dose-dependent manner. The level of Bcl- $\mathrm{X}_{\mathrm{L}}$ expression reached a maximum (fourfold over control;
$P<0.05)$ and remained elevated until day 9 . Moreover, no specific $\mathrm{Bcl}-\mathrm{x}_{\mathrm{S}}$ immunoreactive bands (a proapoptotic isoform) were detected even though three different commercially available antibodies were used (data not shown). 
$\mathbf{A}$

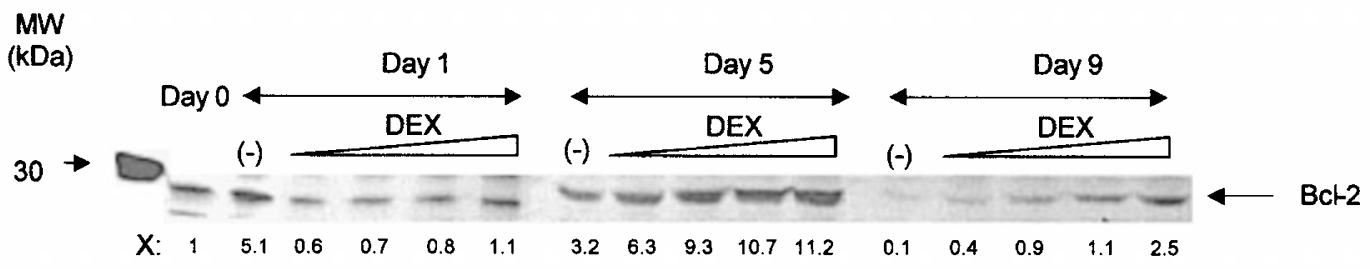

Std.

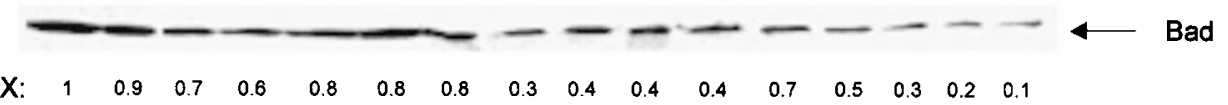

B

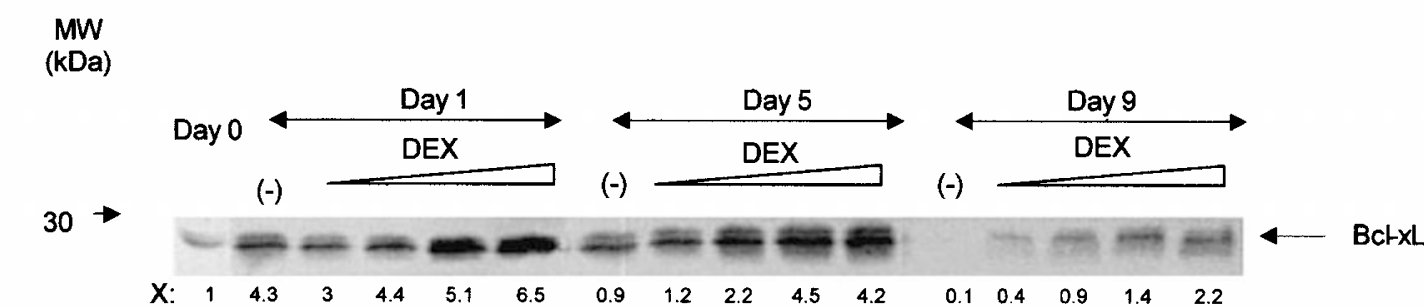

Std.

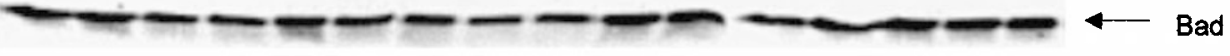

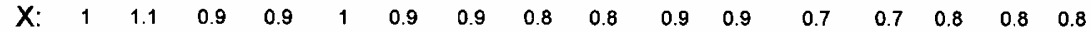

C

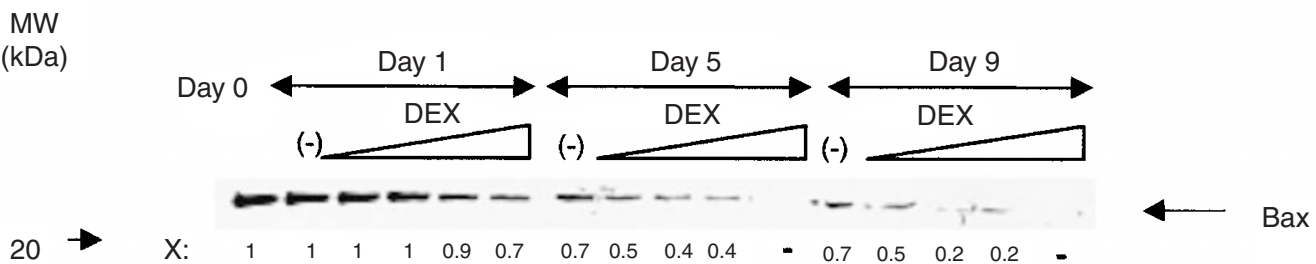

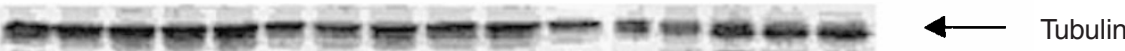

Figure 4 DEX upregulates the levels of the $(A) B c l-2$ protein expression in cultured human hepatocytes $(B) B c l-x_{L}$ protein expression in cultured rat hepatocytes and DEX decreases the level of (C) Bax protein expression in both cell types, in a time- and dose-dependent manner. (A, B and C) After 9 days of treatment with DMSO $(0.25 \%)(-)$ and increasing DEX concentrations $(0.01 \mu \mathrm{M}, 1 \mu \mathrm{M}, 10 \mu \mathrm{M}$, and $50 \mu \mathrm{M})$, total proteins were extracted and the levels of Bcl-2, Bcl- $x_{\mathrm{L}}$ and Bad were analyzed by Western blotting as described in Materials and Methods. Fold inductions were determined as described in Figure 2. The immunoblots shown here represent the typical result from five independent experiments. In (A) and (B) Bad protein levels demonstrate equivalent protein loading and membrane transfer; MW, molecular weight (in $\mathrm{kDa}$ ). In (C) the detection of Tubulin proteins has been included as a control for loading and membrane transfer (Std.)

The levels of Bad protein did not change in response to DEX in total cell extracts (Figure 4A and B). In contrast, the level of expression of Bax protein is downregulated by treatment with DEX in human and rat hepatocytes in a dose-dependent manner (Figure $4 \mathrm{C}$ ). The susceptibility of cells to spontaneous apoptosis may therefore be regulated in part by the ratio of $\mathrm{Bax} / \mathrm{Bcl}-2$ in human hepatocytes and by the ratio of $\mathrm{Bax} / \mathrm{Bcl}-\mathrm{x}_{\mathrm{L}}$ in rat ones.

To further address the role of Bad in spontaneous apoptosis in hepatocytes, we next investigated the effect of DEX on translocation of Bad from the cytosol to the mitochondrial membrane (Figure 3B). We observed an increase in cytosolic Bad protein expression with increasing DEX concentrations, at day 5 by Western blot analysis (Figure 3B), coincident with a decrease in mitochondrial Bad protein. In contrast, the levels of Tubulin (used as a control for loading) and mitochondrial matrix protein, Hsp60 (used as a positive mitochondria control) did not change. Hsp60 was undetectable in cytosolic extracts (Figure 3B).

It has been shown that PI3-kinase and its downstream target, Akt/PKB, phosphorylates Bad. ${ }^{33,34}$ Phosphorylated Bad is sequestered in the cytosol and is bound to 14-3-3 
proteins, thereby impeding apoptosis. ${ }^{35}$ We found two bands corresponding to the Bad protein in the cytosolic extract. The first band could correspond to phosphorytlated form of Bad. These data suggest that spontaneous hepatocyte apoptosis involves the translocation of $\mathrm{Bad}$ to mitochondria as reported by several laboratories. ${ }^{36}$

\section{Effects of dexamethasone on the expression of CAS, and c-Myc proteins}

CAS and c-Myc have been shown to be involved in hepatocyte differentiation and apoptosis. ${ }^{18,19}$ Because CAS and c-Myc expression levels are often correlated with the expression of $\mathrm{Bcl}-2$ family members, we investigated their potential role in spontaneous hepatocyte apoptosis. In vivo, normal hepatocytes revealed no CAS expression. CAS is strongly increased with regenerative proliferation and under pathological conditions such as hepatocellular carcinoma. We found that the expression of the CAS protein was decreased in human hepatocytes treated with increasing concentrations of DEX, from day 1 to day 5 (Figure 5A). Only trace amounts of the CAS protein remained in these cells at day 9 in control and DEX-treated hepatocytes. c-fos and cjun are not expressed in cultured hepatocytes ${ }^{37,38}$ whereas c-myc is constitutively expressed in these cells. ${ }^{8} \mathrm{~A}$ recent study $^{39}$ revealed that c-Myc expression protected hepatocytes from TNF toxicity contradicting the general concept of c-Myc up-regulation as a proapoptotic signal. ${ }^{18}$ As can be seen in Figure 5B, c-Myc expression is upregulated in DEXtreated human hepatocytes compared to untreated-hepatocytes. Similar results were obtained in rat hepatocytes.

\section{Discussion}

In this study we investigated the biochemical pathways leading to spontaneous apoptosis in primary cultures of human and rat hepatocytes and their modulation by dexamethasone (DEX). Current evidence suggests that there are two distinct pathways depending upon the stimulus leading to caspase activation that initiates the death programme : the mitochondrial and the death receptor pathway. (i) The activation of mitochondrial pathway ${ }^{40}$ provokes outer mitochondrial membrane permeabilisation, which results in the release of proteins, such as cytochrome $c$, normally confined to the intermembrane space. Such proteins translocate from the mitochondria to the cytosol by a process controlled by $\mathrm{Bcl}-2$ and $\mathrm{Bcl}-2$-related proteins like $\mathrm{Bcl}-\mathrm{x}_{\mathrm{L}}{ }^{41}$ Once in the cytosol, the so-called apoptosome (cytochrome $\mathrm{cl}$ Apaf-1/procaspase-9) is formed. Activated caspase- 9 then triggers the proteolytic maturation of procaspase-3, setting of

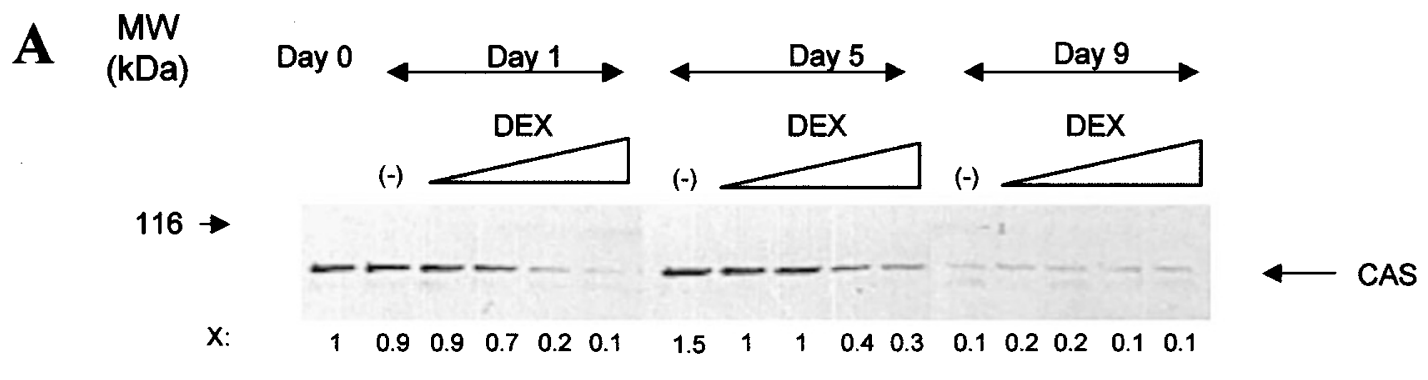

Std.

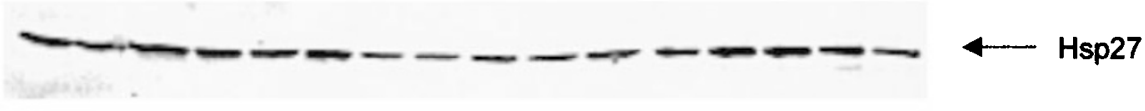

B

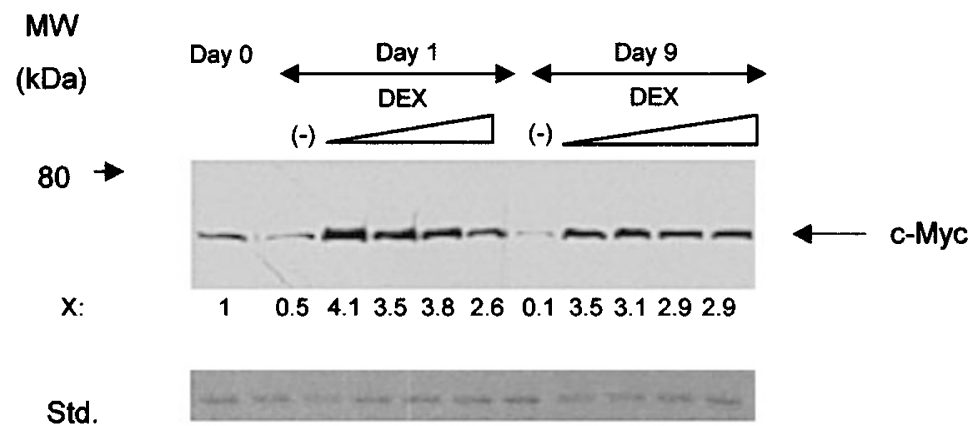

Figure 5 Effects of DEX on CAS, and c-Myc expression in human hepatocytes. The expression of CAS decreases whereas c-Myc expression increases in DEXtreated human hepatocytes. (A) Total lysates were extracted from control cells or DEX-treated cells $(0.01,1,10$ and $50 \mu \mathrm{M})$. The level of CAS was analyzed by Western blot. The blot was reprobed with anti-Hsp27 to demonstrate equivalent protein loading and membrane transfer (Std.). (B) Total proteins were extracted from hepatocytes treated with DMSO (-) or DEX as described below. Western blot analysis was performed with a polyclonal c-Myc antibody (75 ng/ml). Std., control Ponceau of protein loading and membrane transfer; Fold inductions were determined as described below for Figure 2. MW, molecular weight (in kDa) 
the caspase activation ${ }^{14}$ responsible for apoptotic cell death. (ii) The activation of the death receptor pathway provokes the activation of caspase-8 via the recruitment of proteins such as FADD which constitute the death-inducing signalling complex (DISC). ${ }^{42,43}$ Alternative pathways can trigger apoptotic cell death downstream of caspase-8. One implies the direct activation of other caspases, while the other requires the intervention of mitochondria, and therefore converges to the before-mentioned mitochondrial apoptotic pathway. ${ }^{44}$

In this work, our data show that DEX protects primary human and rat hepatocytes against spontaneous apoptosis by modulating a mitochondria-dependent pathway (inhibition of cytocrome $c$ release, and inhibition of the processing of caspase-9, -3 and -8) via inhibition of Bad translocation to mitochondria, decrease in Bax expression and an increase in $\mathrm{Bcl}-2$ and $\mathrm{Bcl}-\mathrm{x}_{\mathrm{L}}$ expression.

We found that caspase- 9 is first activated, followed by caspase- 8 and -3 activation in spontaneous hepatocyte apoptosis. These results are in accordance with the finding that, in cell extracts, caspase- 9 is required for caspase- 3 activation which in turn is required for caspase-8 activation, and participates in a feedback amplification loop involving caspase-9. ${ }^{14,45,46}$ Moreover, recent gene targeting studies provide support for this model. Indeed, no downstream activation of caspase-8 is observed in CASP-9 ${ }^{-1-13}$ and $\mathrm{APAF}^{-1-}$ thymocytes. ${ }^{47}$ Once again, these observations lend support to the observations that caspase- 8 is activated downstream of cytochrome c/Apaf-1. In our hepatocyte model, DEX contributes to delay spontaneous apoptosis by inhibiting this activation of caspases.

In addition, we found that DEX induced an increase in the expression levels of $\mathrm{Bcl}-2$ and $\mathrm{Bcl}-\mathrm{x}_{\mathrm{L}}$ proteins in human and rat hepatocytes, respectively. It has been shown that overexpression of $\mathrm{Bcl}-2$ and $\mathrm{Bcl}-\mathrm{x}_{\mathrm{L}}$ proteins prevents a wide variety of cells from undergoing apoptosis induced by apoptotic stimuli. ${ }^{48,49}$ Interestingly, DEX-inhibited apoptosis is accompanied by a decrease in Bax expression and the accumulation of Bad in the cytosol. Many proapoptotic members of Bcl-2 family are normally found in the cytosol and translocate, after a death signal, to the outer mitochondrial membrane where they act. ${ }^{36,50}$ It appears that, in addition to inhibiting cytochrome $c$ release and processing of caspases, the regulation of $\mathrm{Bcl}-2, \mathrm{Bcl}-\mathrm{x}_{\mathrm{L}}$, and Bax levels, and Bad translocation to mitochondria by DEX is the main pathway in inhibiting apoptosis in hepatocytes. Therefore, all these data are consistent with the idea that DEX mainly protects hepatocytes against spontaneous apoptosis by modulating a mitochondria-dependent pathway.

The family of Hsp proteins represents an important class of apoptosis regulatory gene products. Studies have shown that they inhibit apoptosis by a direct interaction with Apaf-1 and cytochrome $c .^{30}$ In this report, Hsp27 and 70 levels did not change by treatment with DEX indicating that the inhibitory mechanism of DEX on hepatocyte apoptosis may not be related to a regulation of caspase- 9 via these proteins.

To exclude a role of the death receptor pathway in the activation of caspase-8, we investigated Fas, Fas- $L$ and FADD expression since caspase-cascade initiating from caspase- 8 has been extensively evaluated in Fas-mediated hepatocyte apoptosis. ${ }^{10,51}$ Increasing levels of these proteins are often associated with apoptosis. ${ }^{52,53} \mathrm{We}$ observed that the levels of the Fas-L and FADD proteins did not change in control- and DEX-treated cells. These results are consistent with the idea that Fas-L and FADD are not involved in spontaneous hepatocyte apoptosis. In parallel, the level of Fas protein expression did not change in control-hepatocytes but increased following DEX treatment. In vivo hepatocytes express high levels of Fas protein. ${ }^{54}$ Indeed, intravenous injection of anti-Fas antibodies in mice results in the death of the animals through massive liver damage. However, primary cultured hepatocytes are very refractory to anti-Fas antibody treatment (as compared with the in vivo situation), unless protein synthesis is inhibited. In our model, increasing Fas expression by DEX could restore a liver-specific function, by mimicking hepatocyte characteristics in vivo. Fas expression then decreases after day 5 upon DEX treatment coincident with a decreasing differentiated state.

CAS, c-Myc and TIAR proteins have been shown to play roles in apoptosis in various cell types, including hepatocytes. (i) In vivo, normal hepatocytes do not express CAS, however, CAS is only overexpressed in liver pathologies. ${ }^{19}$ In our experiments, we observed a decrease in the expression of CAS in control and DEX-treated hepatocytes. These results are consistent with the idea that CAS protein is not involved in spontaneous apoptosis. (ii) $\mathrm{Bcl}-\mathrm{x}_{\mathrm{L}}$ and $\mathrm{Bcl}-2$ expression appears to be regulated by several transcription factors : NF- $\kappa \mathrm{B}, \mathrm{AP}-1$, STATs and Ets transcription factors. ${ }^{55}$ Moreover, NF- $\kappa \mathrm{B}$ has been shown to be a positive regulator of c-Myc. ${ }^{18}$ Liu et al, demonstrated that inhibition of $\mathrm{c}-\mathrm{Myc}$ mediates hepatocyte sensibility to TNF toxicity independently of NF- $\kappa \mathrm{B} .^{39}$ In our study, DEX treatment leads to the upregulation of $\mathrm{C}$ Myc expression supportive that it contributes to protect hepatocytes against apoptosis. We also examined whether this overexpression was a consequence of NF- $\kappa \mathrm{B}$ upregulation and found that $D E X$-treatment down-regulated NF- $\kappa$ DNA binding activity (data not shown). Thus, c-Myc is probably not a target of $\mathrm{NF}-\kappa \mathrm{B}$ in cultured hepatocytes. Future studies will be needed to investigate the implication of c-Myc and AP-1, Ets, STAT in the upregulation of cellular protective gene(s). (iii) TIAR protein increased in cytosol extracts during spontaneous apoptosis, correlating with the down-regulation of $\mathrm{Bcl}-2$ and $\mathrm{Bcl}-\mathrm{x}_{\mathrm{L}}$. These events are delayed by DEX in a dose-dependent fashion. Taupin et $a^{29}$, have observed a redistribution of TIAR from nucleus to cytosol during lymphocyte apoptosis. Therefore, this redistribution occurring in hepatocytes may reflect a general feature of the apoptotic programme.

The results presented in this paper show that DEX inhibits spontaneous apoptosis in human and rat hepatocytes via a mitochondria-dependent mechanism. In human and rat hepatocytes, increased expression of Bcl-2 and $\mathrm{Bcl}-$ $\mathrm{X}_{\mathrm{L}}$ proteins, respectively, diminution of Bax expression and inhibition of Bad translocation to the mitochondria prevent cytochrome $c$ release to the cytosol, activation of caspases$9,-3$ and -8 , and TIAR redistribution. A summary of the proposed model is presented in Figure 6 . We speculate 


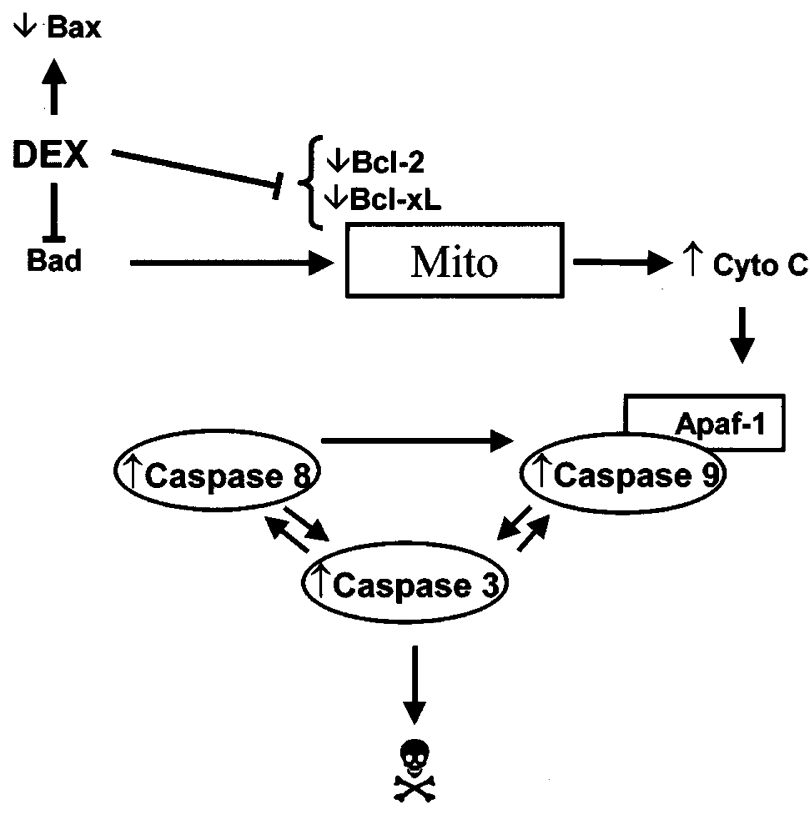

Figure 6 Summary of the proposed mechanism for spontaneous apoptosis in human and rat hepatocytes. When primary human and rat hepatocytes are cultured ex vivo, a few days after seeding and without the addition of an exogenous pro-apoptotic stimulus, bcl-2 and bcl- $x_{\mathrm{L}}$, respectively, are downregulated while Bax is expressed. This would contribute, with the translocation of Bad to the mitochondria, to the release of cytochrome $c$, activation of caspase-9, caspase-3 and caspase-8. Factors, such as dexamethasone (DEX), which are able to up-regulate $\mathrm{Bcl}-2$ and $\mathrm{Bcl}-\mathrm{x}_{\mathrm{L}}$, down-regulate $\mathrm{Bax}$, and inhibit Bad translocation to the mitochondria contribute to inhibit the activation of the caspase cascade in a caspase-9-dependent manner thereby preventing spontaneous apoptosis in human and rat hepatocytes

that arresting the mitochondrial pathway, as we observed with DEX and hence increased survival of primary hepatocytes, will enhance hepatocyte survival ex vivo, thereby enabling future clinical applications (liver transplantation, gene transfer) and drug treatment, toxicology and even cell therapy studies to be possible.

\section{Materials and Methods}

\section{Materials}

Williams' medium E, foetal bovine serum (FBS), DNAzol Reagent, and agarose 1000 were obtained from Gibco BRL (Life Technologies, Paisley, UK) and penicillin/streptomycin from BioWhittaker (Cambrex Company, Walkersville, USA). Collagenase and guanidine thiocyanate were from Boehringer Mannheim (Mannheim Corp; Sydney, Australia), insulin from Nova Nordisk (Nova Nordisk A/S, Bagsvaerd, Denmark) and PicoGreen and RiboGreen from Molecular Probes (Eugene, Oregon, USA). All other chemicals were purchased from Sigma-Aldrich (St. Louis, MO, USA) unless otherwise specified.

\section{Hepatocytes isolation}

Hepatocytes from human surgical liver biopsies (resected from secondary tumours) and from rat liver were isolated by collagenase disruption. ${ }^{56}$ Isolated cells were plated on collagen type l-coated dishes in medium I consisting of Williams' medium E with $10 \%$ FBS, penicillin $(50 \mathrm{U} / \mathrm{ml})$, streptomycin $(50 \mu \mathrm{g} / \mathrm{ml})$ and insulin $(0.1 \mathrm{Ul} / \mathrm{ml})$. Hepatocyte viability was determined by the Erythrosin B exclusion test, and was at least $80 \%$. Hepatocytes were incubated $4 \mathrm{~h}$ at $37^{\circ} \mathrm{C}$ in a humidified atmosphere with $95 \%$ air and $5 \% \mathrm{CO}_{2}$, allowing cell attachment to plates. Medium was changed at that time and replaced by medium II which was identical to the first except that it did not contain serum and was supplemented with hydrocortisone hemisuccinate $(1 \mu \mathrm{M})$ and bovine serum albumin $(240 \mu \mathrm{g} / \mathrm{ml})$ with or without dexamethasone $(0.01$ to $50 \mu \mathrm{M})$.

\section{Cell treatment}

Human and rat hepatocytes were seeded (100000 cells/well) on 96well plates (MTT test), and $60 \mathrm{~mm}$ Petri dishes (caspase activities, Western blot, $\left(2.2 \times 10^{6}\right.$ cells per plates $\left.)\right)$. Hepatocytes were treated over a 9-day period (one treatment every $24 \mathrm{~h}$ ) with $0.01-50 \mu \mathrm{M}$ $\mathrm{DEX}^{9,57}$ which was prepared in dimethylsulfoxide (DMSO) as a carrier and was added directly to cultures when changing the culture medium. The final DMSO concentration never exceeded $0.25 \%(\mathrm{v} / \mathrm{v})$.

\section{In vitro assay for viability}

Cell viability was determined by a colorimetric assay ${ }^{7}$ based on the ability of viable cells, but not dead cells, to reduce $3-(4,5-$ dimethylthiazol-2-yl)-2,5-diphenyl tetrazolium bromide (MTT). This reaction generates a dark blue formazan product. MTT, dissolved in Williams' medium $\mathrm{E}$ at $0.5 \mathrm{mg} / \mathrm{ml}$, was added to each well of the plate, then the plate was incubated at $37^{\circ} \mathrm{C}$ for $2 \mathrm{~h}$. The absorbance at $550 \mathrm{~nm}$ was measured using a microplate reader (MR 7000, Dynatech Laboratories, Inc. USA).

\section{Analysis of cytochrome $c$ release and Bad translocation}

Hepatocytes were scraped off in isotonic isolation buffer $(1 \mathrm{mmol} / \mathrm{l}$ EDTA; $250 \mathrm{mmol} / \mathrm{l}$ sucrose, $10 \mathrm{mM}$ HEPES, $\mathrm{pH}$ 7.6), collected by centrifugation at $2500 \mathrm{~g}$ for $5 \mathrm{~min}$ at $4{ }^{\circ} \mathrm{C}$ and resuspended in hypotonic isolation buffer ( $1 \mathrm{mmol} / / \mathrm{EDTA} ; 50 \mathrm{mmol} / \mathrm{l}$ sucrose, $10 \mathrm{mM}$ HEPES, $\mathrm{pH}$ 7.6). ${ }^{58}$ Then, cells were incubated at $37^{\circ} \mathrm{C}$ for $5 \mathrm{~min}$ and homogenised under a teflon pestle. Hypertonic isolation buffer ( $1 \mathrm{mmol} / \mathrm{I} \mathrm{EDTA} ; 450 \mathrm{mmol} / \mathrm{l}$ sucrose, $10 \mathrm{mM}$ HEPES, $\mathrm{pH}$ 7.6) was added to balance the buffer's tonicity. Samples were centrifuged at 2000 for $5 \mathrm{~min}$ at $4^{\circ} \mathrm{C}$. Supernatants were recovered and centrifuged again at $10000 \mathrm{~g}$ for $10 \mathrm{~min}$. Pellets contained the mitochondrial fraction, which was resuspended in isotonic isolation buffer, and supernatant contained the cytosolic protein extract. Mitochondrial contamination of the cytosolic fraction was determined by Westen-blot analysis of $\mathrm{Hsp60}$ (as described below).

\section{Caspase activity measurement}

Cells were treated as indicated above. After treatments, the Petri dishes were placed on ice and the cells scraped and resuspended in buffer A containing the protease inhibitor cocktail $(25 \mathrm{mM} \mathrm{HEPES} \mathrm{pH}$ 7.5, $5 \mathrm{mM} \mathrm{MgCl}$, $5 \mathrm{mM}$ EDTA, $5 \mathrm{mM}$ DTT, $2 \mathrm{mM}$ PMSF, $10 \mu \mathrm{g} / \mathrm{ml}$ leupeptin, $10 \mu \mathrm{g} / \mathrm{ml}$ pepstatin A). The cell suspension was lysed by four freeze-thaw cycles. Homogenates were centrifuged at 14000 r.p.m. for $20 \mathrm{~min}$ and the protein concentrations of the supernatants were determined by the BCA Protein Assay Kit (Pierce, 
Rockford, IL, USA). Equal amounts of supernatants were mixed in a microtiter plate with $2 \mu \mathrm{l}$ of $2.5 \mathrm{mM}$ Ac-DEVD-AFC, in buffer B (312.5 mM HEPES pH 7.5, 31.25\% sucrose, $0.3125 \%$ CHAPS). The caspase-3-like activity in cell lysates was evaluated by measuring proteolytic cleavage of fluorometric substrate Ac-DEVD-AFC (Alexis Corporation, San Diego, CA, USA). ${ }^{59}$ The fluorometric assay detects the shift in fluorescence emission of AFC after cleavage from DEVDAFC as measured in a fluorometer $\left(\lambda_{\mathrm{ex}}=390 \mathrm{~nm} ; \lambda_{\mathrm{em}}=530 \mathrm{~nm}\right.$ (Fluorolite 1000, Dynatech Laboratories)). In order to calculate caspase 3 specific activity, the fluorescence value obtained in the presence of the specific inhibitor (DEVD-CHO) was subtracted from that in the absence of inhibitor.

\section{Western blot analysis}

Hepatocytes were lysed in RIPA buffer supplemented with $0.1 \%$ SDS. The protein concentration in each cell lysate was measured by a commercial method (BCA Protein Assay Kit), ${ }^{60}$, using BSA as the standard. Fifty micrograms of total protein were resolved on 10 to $12.5 \%$ SDS-polyacrylamide gels and blotted on PVDF membranes (Amersham Life Science, Buckinghamshire, UK). Following staining with Ponceau S ( 0.5 in $1 \%$ acetic acid) to verify loading equivalency and transfer efficiency, membranes were treated with T-TBS (Tris-

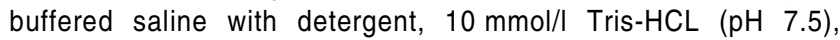
$140 \mathrm{mmol} / \mathrm{l} \mathrm{NaCl}, 0.05 \%$ Tween 20 ) containing $6 \%$ nonfat dry milk for $1 \mathrm{~h}$ at $37^{\circ} \mathrm{C}$ to block non-specific sites. The membrane was then incubated for $1 \mathrm{~h}$ at room temperature with the primary antibody in TTBS containing $3 \%$ BSA. The membrane was washed three times with T-TBS, reacted with horseradish peroxidase-conjugated secondary antibodies (anti-mouse immunoglobulin $\mathrm{G}$ or anti-rabbit immunoglobulin G, Promega, Madison, WI, USA and anti-goat immunoglobulin G, TEBU International, France) for $1 \mathrm{~h}$ at room temperature. After washing with T-TBS, the blot was reacted using an $E C L{ }^{\circledR}$ detection kit (Amersham Life Science). Autoradiography was then performed on the membrane using BIOMAX ML film (Eastman Kodak, Rochester, NY, USA). The blot was reprobed with the following antibodies from Transduction Laboratories: human and rat monoclonal anti-Bcl-2 antibody (clone 7, Transduction Laboratories, Lexington, KY, USA); rat monoclonal anti-Bcl-x antibody (clone 4); human and rat monoclonal anti-Bad antibody (clone 32); human monoclonal anti-procaspase 3 antibody (clone 19); human and rat monoclonal anti-CAS antibody (clone 24); human monoclonal anti-FADD antibody (clone 24); human and rat monoclonal anti-Fas antibody (clone 13); human and rat monoclonal anti-Fas-L antibody (clone 33 ); human and rat monoclonal anti-TIAR antibody (clone 6). The blot was reprobed also with rabbit polyclonal anti-rat procaspase-3 antibody (Upstake Biotechnology Inc., Lake Placid, NY, USA); human and rat polyclonal antibody procaspase-9 (StressGen Biotechnologies Corp., Canada); human and rat polyclonal anti procaspase-8; Hsp27, Hsp60 and Bax (clone SC-526) antibodies (TEBU); human and rat polyclonal anti-Hsp70 antibody (Euromedex, France), human polyclonal c-Myc antibody (Santa Cruz). Monoclonal anti-cytochrome $c$ is from Zymed Laboratories (San Fransisco, CA, USA). Anti- $\beta$ Tubulin (clone 2.1) antibody is from Sigma. Each band was quantified using a densitometer.

\section{Statistics}

The data are expressed as means \pm standard deviations (SD). Statistical significance of differences between various samples was determined by Mann-Whitney $U$-test. The levels of probability are noted $\left({ }^{*}=P<0.05\right.$ or $\left.{ }^{* *}=P<0.001\right)$.

\section{Acknowledgements}

Grant support to KE Boulukos was provided by the Association pour la Recherche contre le Cancer (\#5231). We thank Dr John C Reed for fruitful suggestions and remarks. We thank Dr Patrick Auberger for discussion, critical reading of the manuscript, and gift of anti-Hsp60 and Bax antibodies; Drs Véronique Imbert and Jean-François Peyron for help with EMSA and critical remarks about the manuscript. We thank Sébastien Cagnol, Cécile Terrenoire for the kind gifts of anti-caspase-9, anti-PARP, anti-cytochrome $c$ and Hsp70 antibodies and Dr Nathalie Ledirac for helpful comments and encouragements.

\section{References}

1. Patel T, Roberts LR, Jones BA and Gores GJ (1998) Dysregulation of apoptosis as a mechanism of liver disease: an overview. Semin. Liver Dis. 18: 105-114

2. Columbano $A$ and Shinozuka $H$ (1996) Liver regeneration versus direct hyperplasia. Faseb J. 10: 1118-1128

3. Melino G (2001) The Sirens' song. Nature 412: 23

4. Feldmann G (1997) Liver apoptosis. J. Hepatol. 26 (Suppl 2): 1-11

5. Reed JC and Tomaselli KJ (2000) Drug discovery opportunities from apoptosis research. Curr. Opin. Biotechnol. 11: 586-592

6 LeCluyse EL, Bullock PL, Parkinson A and Hochman JH (1996) Cultured rat hepatocytes. Pharm. Biotechnol. 8: 121-159

7. Kim YM, Talanian RV and Billiar TR (1997) Nitric oxide inhibits apoptosis by preventing increases in caspase-3-like activity via two distinct mechanisms. J. Biol. Chem. 272: 31138-31148

8. De Smet K, Loyer P, Gilot D, Vercruysse A, Rogiers V and Guguen-Guillouzo $C$ (2001) Effects of epidermal growth factor on CYP inducibility by xenobiotics, DNA replication, and caspase activations in collagen I gel sandwich cultures of rat hepatocytes. Biochem. Pharmacol. 61: 1293-1303

9. Bailly-Maitre B, de Sousa G, Boulukos K, Gugenheim J and Rahmani R (2001) Dexamethasone inhibits spontaneous apoptosis in primary cultures of human and rathepatocytes via Bcl-2 and Bcl-xL induction. Cell Death Differ. 8:279-288

10. Nagata S (1997) Apoptosis by death factor. Cell. 88: 355-365

11. Enari M, Sakahira H, Yokoyama H, Okawa K, Iwamatsu A and Nagata S (1998) A caspase-activated DNase that degrades DNA during apoptosis, and its inhibitor ICAD. Nature 391: 43-50

12. Varfolomeev EE, Schuchmann M, Luria V, Chiannilkulchai N, Beckmann JS, Mett IL, Rebrikov D, Brodianski VM, Kemper OC, Kollet O, Lapidot T, Soffer D, Sobe T, Avraham KB, Goncharov T, Holtmann H, Lonai P and Wallach D (1998) Targeted disruption of the mouse Caspase 8 gene ablates cell death induction by the TNF receptors, Fas/Ap01, and DR3 and is lethal prenatally. Immunity 9:267276

13. Hakem R, Hakem A, Duncan GS, Henderson JT, Woo M, Soengas MS, Elia A, de la Pompa JL, Kagi D, Khoo W, Potter J, Yoshida R, Kaufman SA, Lowe SW, Penninger JM and Mak TW (1998) Differential requirement for caspase 9 in apoptotic pathways in vivo. Cell 94: 339-352

14. Li P, Nijhawan D, Budihardjo I, Srinivasula SM, Ahmad M, Alnemri ES and Wang $X$ (1997) Cytochrome $c$ and dATP-dependent formation of Apaf-1/caspase- 9 complex initiates an apoptotic protease cascade. Cell. 91: 479-489

15. Yang X, Chang HY and Baltimore D (1998) Essential role of CED-4 oligomerization in CED-3 activation and apoptosis. Science 281: 1355-1357

16. Kluck RM, Bossy-Wetzel E, Green DR and Newmeyer DD (1997) The release of cytochrome c from mitochondria: a primary site for $\mathrm{Bcl}-2$ regulation of apoptosis. Science 275: $1132-1136$

17. Shimizu S, Narita M and Tsujimoto Y (1999) Bcl-2 family proteins regulate the release of apoptogenic cytochrome $\mathrm{c}$ by the mitochondrial channel VDAC. Nature 399: 483-487

18. Evan G and Littlewood T (1998) A matter of life and cell death. Science 281: $1317-1322$

19. Wellmann A, Flemming P, Behrens $P$, Wuppermann K, Lang H, Oldhafer K, Pastan I and Brinkmann U (2001) High expression of the proliferation and apoptosis associated CSE1L/CAS gene in hepatitis and liver neoplasms: correlation with tumor progression. Int. J. Mol. Med. 7: 489-494.

20. Peiro G, Diebold J, Baretton GB, Kimmig R and Lohrs U (2001) Cellular apoptosis susceptibility gene expression in endometrial carcinoma: correlation with Bcl-2, Bax, and caspase-3 expression and outcome. Int. J. Gynecol. Pathol. 20: 359-367 
21. Piecyk M, Wax S, Beck AR, Kedersha N, Gupta M, Maritim B, Chen S, Gueydan C, Kruys V, Streuli M and Anderson P (2000) TIA-1 is a translational silencer that selectively regulates the expression of TNF-alpha. EMBO J. 19: 4154-4163

22. Thompson CB (1995) Apoptosis in the pathogenesis and treatment of disease. Science 267: 1456 - 1462

23. Juo $P, K u o ~ C J$, Yuan J and Blenis J (1998) Essential requirement for caspase-8/ FLICE in the initiation of the Fas-induced apoptotic cascade. Curr. Biol. 8: 1001 1008

24. Kuida K, HaydarTF, Kuan CY, GuY, Taya C, Karasuyama H, Su MS, Rakic P and Flavell RA (1998) Reduced apoptosis and cytochrome c-mediated caspase activation in mice lacking caspase 9. Cell 94: 325-337

25. Scaffidi C, Medema JP, Krammer PH and Peter ME (1997) FLICE is predominantly expressed as two functionally active isoforms, caspase-8/a and caspase-8/b. J. Biol. Chem. 272: 26953-26958

26. Alnemri ES, Livingston DJ, Nicholson DW, Salvesen G, Thornberry NA, Wong WW and Yuan J (1996) Human ICE/CED-3 protease nomenclature. Cell. 87:171

27. Enari M, Talanian RV, Wong WW and Nagata S (1996) Sequential activation of ICE-like and CPP32-like proteases during Fas-mediated apoptosis. Nature 380 : 723-736

28. Bump NJ, Hackett M, Hugunin M, Seshagiri S, Brady K, Chen P, Ferenz C Franklin S, Ghayur T, Li P, Licari P, Mankovich J, Shi L, Greenberg AH, Miller LK and Wong WW (1995) Inhibition of ICE family proteases by baculovirus antiapoptotic protein p35. Science 269: 1885-1888

29. Taupin JL, Tian Q, Kedersha N, Robertson M and Anderson P (1995) The RNAbinding protein TIAR is translocated from the nucleus to the cytoplasm during Fas-mediated apoptotic cell death. Proc. Natl. Acad. Sci. USA. 92: 1629-1633

30. Garrido C, Gurbuxani S, Ravagnan Land Kroemer G (2001) Heat shock proteins: endogenous modulators of apoptotic cell death. Biochem. Biophys. Res. Commun. 286: 433-442

31. Reed JC (1997) Cytochrome c: can't live with it-can't live without it. Cell. 91: $559-562$.

32. Chao DT and Korsmeyer SJ (1998) BCL-2 family regulators of cell death. Annu. Rev. Immunol. 16: 395-419

33. Datta SR, Dudek H, Tao X, Masters S, Fu H, Gotoh Y and Greenberg ME (1997) Akt phosphorylation of BAD couples survival signals to the cell-intrinsic death machinery. Cell. 91: 231-241

34. del Peso L, Gonzalez-Garcia M, Page C, Herrera R and Nunez G (1997) Interleukin-3-induced phosphorylation of BAD through the protein kinase Akt. Science 278:687-689

35. Zha J, Harada H, Yang E, Jockel J and Korsmeyer SJ (1996) Serine phosphorylation of death agonist BAD in response to survival factor results in binding to 14-3-3 not BCL-X(L). Cell. 87: 619-628

36. Desagher S and Martinou JC (2000) Mitochondria as the central control point of apoptosis. Trends Cell Biol. 10: 369-377

37. Etienne PL, Baffet G, Desvergne B, Boisnard-Rissel M, Glaise D and GuguenGuillouzo C (1988) Transient expression of c-fos and constant expression of Cmyc in freshly isolated and cultured normal adult rat hepatocytes. Oncogene Res. 3: 255-262

38. Loyer P, Cariou S, Glaise D, Bilodeau M, Baffet G and Guguen-Guillouzo C (1996) Growth factor dependence of progression through G1 and S phases of adult rat hepatocytes in vitro. Evidence of a mitogen restriction point in mid-late G1. J. Biol. Chem. 271: 11484-11492

39. Liu H, Lo CR, Jones BE, Pradhan Z, Srinivasan A, Valentino KL, Stockert RJ and Czaja MJ (2000) Inhibition of c-Myc expression sensitizes hepatocytes to tumor necrosis factor-induced apoptosis and necrosis. J. Biol. Chem. 275: 4015540162

40. Ferri KF and Kroemer G (2001) Mitochondria : the suicide organelles. Bioessays 23: $111-115$

41. Kroemer $G$ and Reed JC (2000) Mitochondrial control of cell death. Nat. Med. 6 : $513-519$
42. Kim YM, Kim TH, Chung HT, Talanian RV, Yin XM and Billiar TR (2000) Nitric oxide prevents tumor necrosis factor alpha-induced rat hepatocyte apoptosis by the interruption of mitochondrial apoptotic signaling through S-nitrosylation of caspase-8. Hepatology 32: 770-778

43. Shima Y, Nakao K, Nakashima T, Kawakami A, Nakata K, Hamasaki K, Kato Y, EguchiKand Ishii N (1999) Activation of caspase-8 in transforming growth factorbeta-induced apoptosis of human hepatoma cells. Hepatology 30: 1215-1222

44. Scaffidi C, Schmitz I, Zha J, Korsmeyer SJ, Krammer PH and Peter ME (1999) Differential modulation of apoptosis sensitivity in CD95 type I and type II cells. J. Biol. Chem. 274: 22532-22538

45. Slee EA, Adrain C and Martin SJ (1999) Serial killers: ordering caspase activation events in apoptosis. Cell Death Differ. 6: 1067-1074

46. Slee EA, Harte MT, Kluck RM, Wolf BB, Casiano CA, Newmeyer DD, Wang HG, Reed JC, Nicholson DW, Alnemri ES, Green DR and Martin SJ (1999) Ordering the cytochrome $c$-initiated caspase cascade: hierarchical activation of caspases-2, $-3,-6,-7,-8$, and -10 in a caspase-9-dependent manner. J. Cell. Biol. 144: 281-292

47. Yoshida H, Kong YY, Yoshida R, Elia AJ, Hakem A, Hakem R, Penninger JM and Mak TW (1998) Apaf1 is required for mitochondrial pathways of apoptosis and brain development. Cell 94: 739-750

48. Adams JM and Cory S (1998) The Bcl-2 protein family: arbiters of cell survival. Science 281: $1322-1326$

49. Fadeel B, Zhivotovsky B and Orrenius S (1999) All along the watchtower: on the regulation of apoptosis regulators. FASEB J. 13: 1647-1657

50. Hsu SY, Kaipia A, Zhu L and Hsueh AJ (1997) Interference of BAD (Bcl-xL/Bcl-2associated death promoter)-induced apoptosis in mammalian cells by 14-3-3 isoforms and P11. Mol. Endocrinol. 11: 1858-1867

51. Jones RA, Johnson VL, Buck NR, Dobrota M, Hinton RH, Chow SC and Kass GE (1998) Fas-mediated apoptosis in mouse hepatocytes involves the processing and activation of caspases. Hepatology 27: 1632-1642

52. Muzio M, Chinnaiyan AM, Kischkel FC, O'RourkeK, Shevchenko A, Ni J, Scaffid C, Bretz JD, Zhang M, Gentz R, Mann M, Krammer PH, Peter ME and Dixit VM (1996) FLICE, a novel FADD-homologous ICE/CED-3-like protease, is recruited to the CD95 (Fas/APO-1) death-inducing signaling complex. Cell 85: 817-827

53. Muschen M, Warskulat U, Douillard P, Gilbert E and Haussinger D (1998) Regulation of CD95 (APO-1/Fas) receptor and ligand expression by lipopolysaccharide and dexamethasone in parenchymal and nonparenchymal rat liver cells. Hepatology 27: 200-208

54. Ogasawara J, Watanabe-Fukunaga R, Adachi M, Matsuzawa A, Kasugai T, Kitamura Y, Itoh N, Suda T and Nagata S (1993) Lethal effect of the anti-Fas antibody in mice. Nature 364: 806-809

55. Sevilla L, Zaldumbide A, Pognonec P and Boulukos KE (2001) Transcriptional regulation of the bcl- $x$ gene encoding the anti-apoptotic $B c l-x L$ protein by Ets, Rel/NFkappaB, STAT and AP1 transcription factor families. Histol. Histopathol. 16: $595-601$

56. Berry MN and Friend DS (1969) High-yield preparation of isolated rat liver parenchymal cells: a biochemical and fine structural study. J. Cell. Biol. 43:506 520

57. Marre F, Sanderink GJ, de Sousa G, Gaillard C, Martinet M and Rahmani R (1996) Hepatic biotransformation of docetaxel (Taxotere) in vitro: involvement of the CYP3A subfamily in humans. Cancer Res. 56: 1296-1302

58. Herrera B, Alvarez AM, Sanchez A, Fernandez M, Roncero C, Benito M and Fabregat I (2001) Reactive oxygen species (ROS) mediates the mitochondrialdependent apoptosis induced by transforming growth factor (beta) in fetal hepatocytes. FASEB J. 15: 741-751

59. Gurtu V, Kain SR and Zhang G (1997) Fluorometric and colorimetric detection of caspase activity associated with apoptosis. Anal Biochem. 251: 98-102

60. Smith PK, Krohn RI, Hermanson GT, Mallia AK, Gartner FH, Provenzano MD, Fujimoto EK, Goeke NM, Olson BJ and Klenk DC (1985) Measurement of protein using bicinchoninic acid. Anal Biochem. 150: 76-85 